\title{
Evaluation of the Microbiological and Nutritional Quality of Fermented-Dried Lesser African Threadfin (Galeoides decadactylus) Used as Food Supplement in Southern Benin
}

\author{
René G. Dègnon ${ }^{1 *}$, Euloge S. Adjou ${ }^{1}$, Edwige Dahouenon-Ahoussi ${ }^{1}$, \\ Mohamed M. Soumanou ${ }^{1}$, Emile Fiogbé ${ }^{2}$ \\ ${ }^{1}$ Laboratory of Research and Study in Applied Chemistry, Polytechnic School of Abomey-Calavi, \\ University of Abomey-Calavi, Cotonou, Benin \\ ${ }^{2}$ Laboratory of Research on Wetlands, Faculty of Sciences and Technics, \\ University of Abomey-Calavi, Cotonou, Bénin \\ Email: "gnimabou2000@yahoo.fr
}

Received November 7, 2013; revised December 9, 2013; accepted January 5, 2014

Copyright (C 2014 René G. Dègnon et al. This is an open access article distributed under the Creative Commons Attribution License, which permits unrestricted use, distribution, and reproduction in any medium, provided the original work is properly cited. In accordance of the Creative Commons Attribution License all Copyrights @ 2014 are reserved for SCIRP and the owner of the intellectual property René G. Dègnon et al. All Copyright @ 2014 are guarded by law and by SCIRP as a guardian.

\section{ABSTRACT}

Lesser African threadfin (Galeoides decadactylus) is a nutritious marine fish, popular and widely used for drying-fermentation. The present work aims to evaluate the nutritional and microbiological quality of dried-fermented Lesser African Threadfin, currently used in food preparing in southern Benin. Four major sites of drying-fermentation fishes in southern Benin were investigated and dried-fermented Lesser African Threadfin was collected for quality control. Results indicated that the dried-fermented fishes were good sources of nutriments with a moisture content ranging from $44.62 \% \pm 0.68 \%$ to $55.33 \% \pm 0.23 \%$. Proteins contents are ranged from $\mathbf{1 5 . 2 6 \%} \pm \mathbf{0 . 3 2} \%$ to $22.95 \% \pm \mathbf{0 . 7 1 \%}$. All samples analyzed were rich in minerals such as magnesium, phosphorus, iron, with a higher content of calcium $(1.23 \% \pm 0.52 \%-1.69 \% \pm 0.38 \%)$. Statistical analyses showed significant difference $(p<0.05)$ between samples analyzed. Microbiological analyses revealed that the total flora count of samples ranged from $1.4 \times 10^{2}$ to $8.0 \times 10^{4} \mathrm{ufc} / \mathrm{g}$. The enumeration of total coliforms and fecal coliforms indicated that samples were contaminated with enteric bacteria. The spores of anaerobic sulfite reducer's and Staphylococcus aureus counts were less than $10 \mathrm{cfu} / \mathrm{g}$ with an absence of Salmonella spp. Based on results from the present study, microbiological standards must be put in place during the process of dried-fermented fishes. Then, it's advisable that relevant quality control unit should be reactivated to assess the quality of ready-to-eat food, and particularly the fermented fishes in other to protect consumer's health.

\section{KEYWORDS}

Galeoides decadactylus; Drying-Fermentation; Nutritional and Microbiological Quality; Benin

\section{Introduction}

The lack of animal protein in the human diet is one of the most characteristics of developing countries. This protein deficiency, particularly, affects children. Fish and fish products have an important place in the diet of the people of West Africa [1]. In Republic of Benin, fishing has an important place in the national socio-economic balance as it sustains some 500,000 people and accounts for $3 \%$

\footnotetext{
"Corresponding author.
}

of GDP [2]. However, the conservation of fish is very difficult due to the lack of adequate conservation system and post-harvest losses are estimated at about 20\% [3]. To overcome this problem, the fermentation of fish is the one of usually method of preserving fish in Benin, and is still made in the traditional way [4]. Generally, Food fermentation is the study of microbial activity, usually anaerobic, on suitable substrates under controlled or uncontrolled conditions resulting in production of desirable foods or beverages that are characteristically more stable, 
palatable and nutritious than the raw substrate [5]. In Benin, fisheries produce fermented fish from some fish species. During the production, producers get losses of products because of unpleasant practices and uncontrolled phenomena [4]. Over than one hundred species of fish lived in marine waters under Benin jurisdiction and fish biomass was estimated by CECAF (Fishery Committee for the Eastern Central Atlantic) in 1988, at 9660 tons of pelagic fish and about 6000 tons of demersal fish. Among demersal fish species are the Lesser African Threadfin (Galeoides decadactylus). Its post-harvest losses are very important because of the very soft nature of its fleshes. Various treatments are performed to reduce these losses. The fermentation and drying to produce the "lanhouin" is one of the control strategies of loss reduction currently used in Benin [4]. The "lanhouin" is the salted, fermented and dried fish usually consumed in southern Benin. This process is still artisanal and the presence of flies and other insects during the process could lead to the presence of undesired pathogens microorganisms and can also affect the nutritional value of the product. Then the present work aims to evaluate the microbiological quality and the nutritional potential of the fermented-dried Lesser African Threadfin (Galeoides decadactylus) during the process.

\section{Material and Methods}

\subsection{Sampling}

Four sites of fish drying-fermentation localized at Avle- kete, Meko, Akpakpa-dodomè and Cotonou (Artisanal Fisheries Port) were investigated (Figure 1). Site selection was done taking into account both the presence of large processors and secondly the fact that these sites represent the large areas of fish drying-fermentation in southern Benin. In addition, the Lesser African Threadfin is one of the most species fish treated on these sites. In each site, five process points were chosen and one (01) kilogram of Lesser African Threadfin dried-fermented was collected. The sampling was performed under aseptic conditions: sterile latex gloves are used to protect hands during the sampling; fish samples are collected and packaged in sterile bags and packaged in a portable cooler. The entire sampling equipment is sterilized beforehand with alcohol at $90^{\circ} \mathrm{C}$. Samples were sent to the laboratory for the microbiological, physiochemical and nutritional analyses.

\subsection{Microbiological Analysis}

For microbiological analysis, $25 \mathrm{~g}$ of each sample and $225 \mathrm{ml}$ of peptone water was added and homogenized. From the initial concentration, appropriate decimal dilutions were prepared and aliquots were plated in duplicates on various media. Plate count agar was used for the total bacterial count. Plates were incubated at $30^{\circ} \mathrm{C}$ for 72 h. Desoxycholate was used for the total coliforms count and plates were incubated at $30^{\circ} \mathrm{C}$ for $24 \mathrm{~h}$. Desoxycholate was also used for the faecal coliforms count. In this case, plates were incubated at $44^{\circ} \mathrm{C}$ and the identification

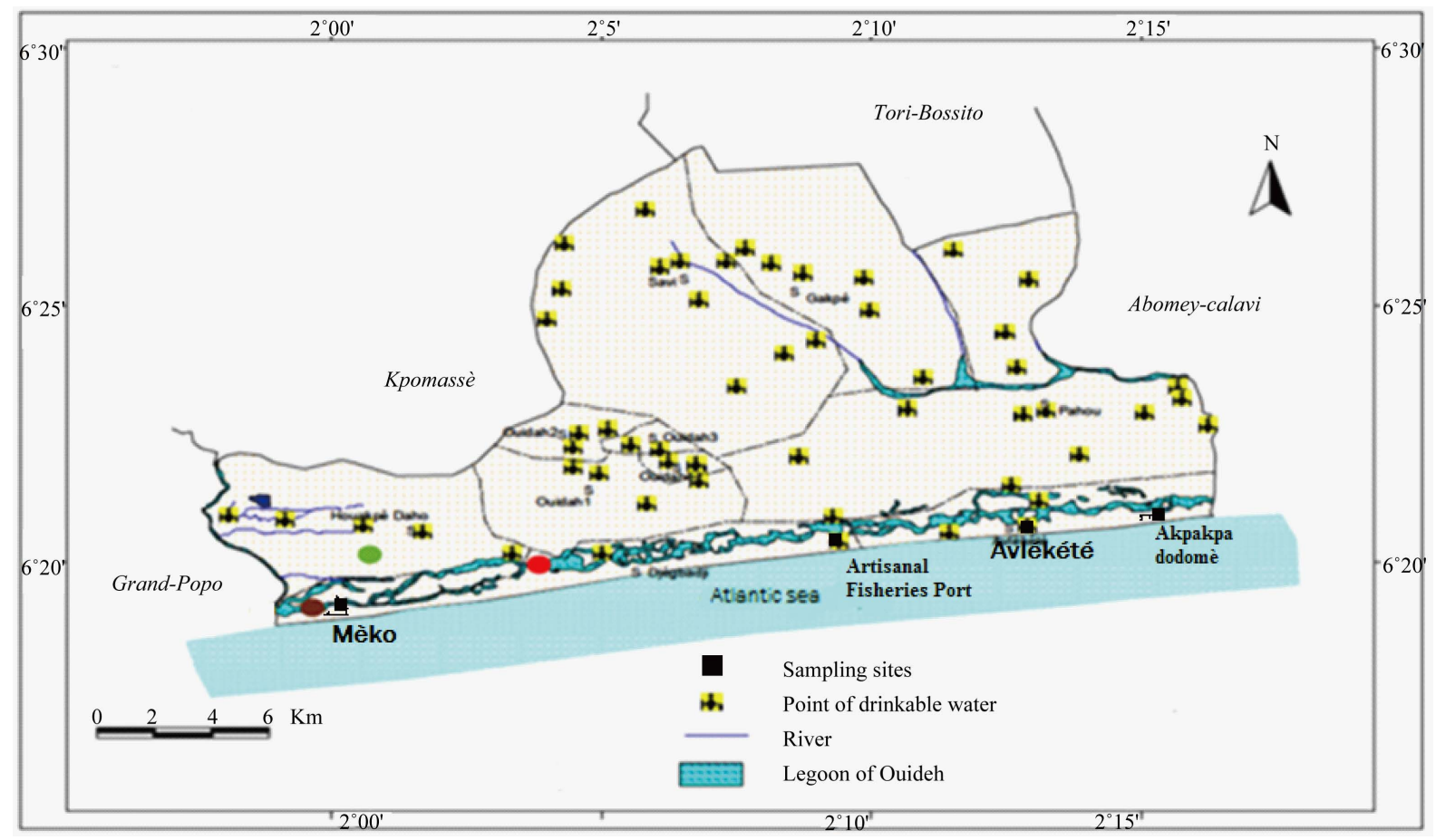

Figure 1. Map of the coastal zone of Ouidah (Southern Benin) with sampling sites. 
was made using Eosine methylene blue (EMB) medium. Tryptone sulfite neomicin agar was used for anaerobic sulfito-reducer (ASR) count, and tubes were incubated at $37^{\circ} \mathrm{C}$ for 24 h. Staphylococcus aureus count was performed as described by the standard NF EN ISO 6888-1. The method used for detection of Salmonella spp. is that specified by the standard NF V 08-052. After incubation, the number of colonies was tracked, using a colony counter. The number of bacteria expressed as Colony Forming Units per gram (CFU/g) was then determined by calculation, bearing in mind the factors of dilution. All media used for microbiological analysis were prepared as indicated by the manufacturer.

\subsection{Determination of Physicochemical Parameters}

Moisture content of samples was determined by desiccation using the method of De Knegt and Brink [6]. A clean platinum dish was dried in an oven and cooled in a desiccator and weighed. From each sample, $5 \mathrm{~g}$ was weighed and spread on the dish, the dish containing the sample was weighed. It was then transferred into the air oven at $105^{\circ} \mathrm{C}$ to dry until a constant weight was obtained and the loss in mass was determined.

\subsection{Nutritional Analysis}

Protein was analyzed by the Microkjedhal nitrogen method. Minerals were analyzed by the method reported by Oshodi [7]. Ash was determined according to the standard methods described by the Association of Official Analytical Chemists [8]. Minerals were analyzed by dryashing $1 \mathrm{~g}$ of the sample at $550^{\circ} \mathrm{C}$ in a furnace. The ash obtained was dissolved in $10 \% \mathrm{HCl}$, filtered with filter paper and made up to standard volume with deionised water. Flame photometer was used to determine phosphorus content of the samples, while calcium, iron and magnesium were determined using atomic absorption spectrophotometer (Perkin Elmer, Model 403).

\subsection{Statistical Analyses}

The data generated from these studies were analyzed using Statistical Analysis Software (SAS) and SYSTAT 5.05. The statistical analyses carried out were mean and standard deviation and analysis of variance (ANOVA) [9, $10]$.

\section{Results and Discussion}

The results of physicochemical and nutritional characterization of different samples of dried-fermented fishes (Table 1) showed that the moisture content of different samples ranged from $44.62 \% \pm 0.68 \%$ to $55.33 \% \pm$ $0.23 \%$. The dried-fermented fishes collected are rich in nutrients such as proteins $(15.26 \% \pm 0.32 \%-22.95 \% \pm$ $0.71 \%)$, ash $(22.09 \% \pm 0.57 \%-29.43 \% \pm 0.61 \%)$. All samples analyzed were rich in minerals such as magnesium $(0.59 \% \pm 0.01 \%-0.06 \% \pm 0.02 \%)$, phosphorus $(0.72 \% \pm 0.01 \%-1.14 \% \pm 0.07 \%)$, iron $(0.29 \% \pm 0.02 \%$ - $0.39 \% \pm 0.01 \%)$, with a higher content of calcium $(1.23 \% \pm 0.52 \%-1.69 \% \pm 0.38 \%)$. Statistical analyses showed significant difference $(\mathrm{p}<0.05)$ between samples analyzed. Microbiological analyses revealed that the total flora count of samples ranged from $1.4 \times 10^{2}$ to 8.0 $\times 10^{4} \mathrm{ufc} / \mathrm{g}$. The enumeration of total coliforms and fecal coliforms indicated that samples are contaminated with enteric bacteria. The spores of anaerobic sulfite reducers count and Staphylococcus aureus count was less than 10 cfu/g with an absence of Salmonella spp. (Table 2).

The results of the proximate composition revealed that

Table 1. Physicochemical and nutritional qualities of dried-fermented fishes.

\begin{tabular}{cccccccc}
\hline Sampling sites & Moisture (\%) & Ash (\%) & Protein (\%) & Iron (mg/kg) & Calcium (\%) & Magnesium (\%) & Phosphorus (\%) \\
\hline Avlekete & $55.33 \pm 0.23^{\mathrm{a}}$ & $24.63 \pm 0.32^{\mathrm{a}}$ & $15.26 \pm 0.32^{\mathrm{a}}$ & $0.29 \pm 0.02^{\mathrm{a}}$ & $1.23 \pm 0.52^{\mathrm{a}}$ & $0.09 \pm 0.02^{\mathrm{a}}$ & $0.82 \pm 0.05^{\mathrm{a}}$ \\
Meko & $46.97 \pm 0.57^{\mathrm{b}}$ & $22.09 \pm 0.57^{\mathrm{a}}$ & $22.72 \pm 0.45^{\mathrm{b}}$ & $0.34 \pm 0.05^{\mathrm{a}}$ & $1.69 \pm 0.38^{\mathrm{b}}$ & $0.59 \pm 0.01^{\mathrm{b}}$ & $1.14 \pm 0.07^{\mathrm{b}}$ \\
Akpakpa-dodome & $48.53 \pm 0.49^{\mathrm{b}}$ & $29.43 \pm 0.61^{\mathrm{b}}$ & $16.87 \pm 0.61^{\mathrm{a}}$ & $0.36 \pm 0.07^{\mathrm{a}}$ & $1.28 \pm 0.31^{\mathrm{a}}$ & $0.06 \pm 0.01^{\mathrm{a}}$ & $0.72 \pm 0.01^{\mathrm{a}}$ \\
Cotonou & $44.62 \pm 0.68^{\mathrm{b}}$ & $25.47 \pm 0.26^{\mathrm{a}}$ & $22.95 \pm 0.71^{\mathrm{b}}$ & $0.39 \pm 0.01^{\mathrm{b}}$ & $1.84 \pm 0.52^{\mathrm{b}}$ & $0.12 \pm 0.02^{\mathrm{a}}$ & $1.06 \pm 0.09^{\mathrm{b}}$ \\
\hline
\end{tabular}

Values are mean $(\mathrm{n}=3) \pm \mathrm{SE}$. The means followed by same letter in the same column are not significantly different according to ANOVA and Tukey’s multiple comparison tests.

Table 2. Microbiological quality of dried-fermented fishes.

\begin{tabular}{|c|c|c|c|c|c|c|}
\hline Sampling sites & $\begin{array}{c}\text { Total } \\
\text { Bacterial count }\end{array}$ & $\begin{array}{c}\text { Total Coliforms } \\
\text { count }\end{array}$ & $\begin{array}{c}\text { Faecal } \\
\text { Coliforms count }\end{array}$ & $\begin{array}{c}\text { A.S.R } \\
\text { Spores count }\end{array}$ & $\begin{array}{l}\text { Staphylococcus } \\
\text { aureus count }\end{array}$ & $\begin{array}{c}\text { Salmonella spp. } \\
\text { count }\end{array}$ \\
\hline Avlekete & $2.5 \times 10^{2}$ & $<10^{2}$ & 10 & $<10$ & 10 & Absence \\
\hline Cotonou & $1.4 \times 10^{2}$ & $>10^{2}$ & $2.1 \times 10^{2}$ & $<10$ & $<10$ & Absence \\
\hline Akpakpa-dodome & $1.5 \times 10^{2}$ & $>10^{2}$ & $2.4 \times 10^{2}$ & $<10$ & $<10$ & Absence \\
\hline
\end{tabular}


Lesser African Threadfin (Galeoides decadactylus) dryed-fermented are good source of proteins and minerals such as magnesium, phosphorus, iron, and calcium. Protein content is less than those reported by DossouYovo et al. [4] in Pseudotolithus senegalensis (Cassava croaker) and Scomberomorus tritor (Spanish mackerel). These differences could be due to the protein content of these fishes before their fermentation. In fact, according to Dossou-Yovo et al. [4], the biochemical characteristics of Lesser African Threadfin (Galeoides decadactylus) was protein (20.4\%), lipid (1.4\%) and minerals (12.0\%). This protein content of fresh fish was similar to those obtained in the dried-fermented fish. However, minerals content of dried-fermented fish is higher than those reported in fresh Lesser African Threadfin. Statistical analyses also revealed significant difference in the nutritional content of the dried-fermented Lesser African Threadfin depend on the sampling sites. This different could be due to the variability observed in the process of driedfermented fish, mainly during fermentation and sun drying durations (Figures 2 and 3).

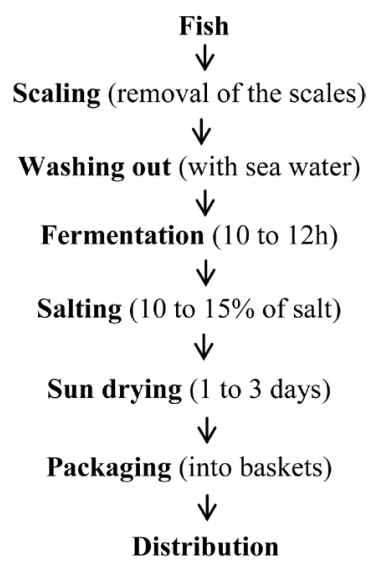

Figure 2. Technical diagram of drying-fermented fish in surveyed sites.

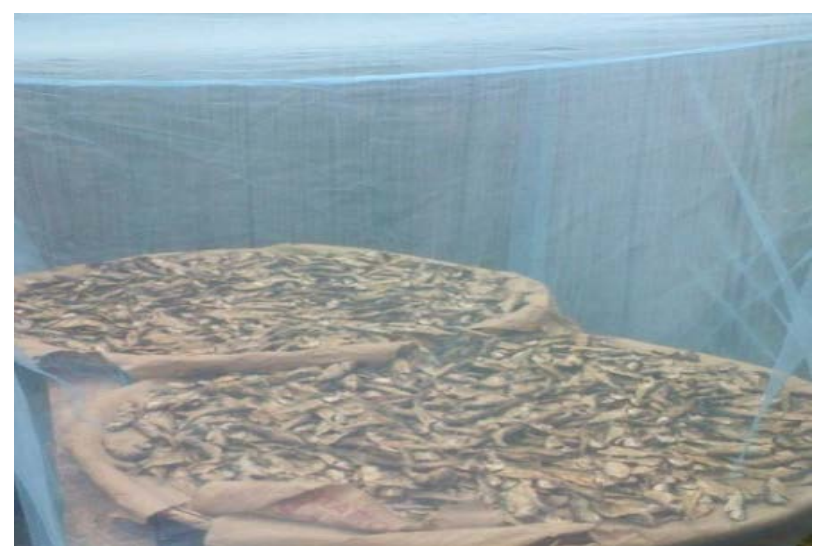

Figure 3. Improvement method of fermented-dried Lesser African Threadfin using clothes for protection against insects or others parasites.
These results indicated that the fermentation of fish may contribute to upgrade its nutritional value and the bioavailability of nutrients. Based on its nutritional potential, Lesser African Threadfin dried-fermented can use as ingredients for making infant flour is an interesting alternative that it should help to diversify infant complementary feeding. Indeed, infants and young children are often regarded as two particularly vulnerable groups in terms of food safety. Furthermore, the requirements for essential nutrients due to rapid growth and development put these groups at risk of deficiencies of essential minerals. It is therefore essential that products intended for use by infants and young children contain minerals in amounts that satisfy their nutritional requirements without leading to adverse effects. Minerals are important in human nutrition. It is well known that enzymatic activities as well as electrolyte balance of the blood fluid are related to adequacy of $\mathrm{Na}, \mathrm{K}$, and $\mathrm{Mg}$. Potassium is very important in maintaining the body fluid volume and osmotic equilibrium. Metal deficiency syndrome like rickets and calcification of bones is caused by calcium deficiency. The high values of calcium, phosphorus, and magnesium indicated that Lesser African Threadfin dried-fermented can play a vital role in the development of bones, teeth, co-factor in enzymatic reaction, nerve impulse transmission and as a clotting factor [11]. The consumption of these fermented fishes will also help to alleviate symptoms of magnesium and zinc deficiency such as weakness, cardial arrhythmia, poor growth, impairment of sexual development. Several studies on nutrition in developing countries have shown that adequate nutrient intake (daily calories, daily protein, daily fat, minerals and vitamins) is an essential ingredient for improved well-being, economic growth and development, since a healthy body enhances the capacity to learn which in turn determines productivity and economic growth [12].

Results obtained from microbial analysis of driedfermented Lesser African Threadfin showed that they were contaminated with microorganisms. The high total bacterial and coliform count may be a consequence of the low level of hygiene maintained during the processing. This includes the handlers, quality of ingredients used for dressing and the utensils. During the sale, dirty hands are dipped into the bowl for product selection by both hawkers and consumers. The exposure of products while they were displayed for sale can serve as source of contamination. The detection of coliforms may indicate poor hygienic practice among handlers of products. Moreover, the contamination of the dried-fermented Lesser African Threadfin, could be also in relation with the previous quality of the fishes before their procession. Indeed, human activity causes the production of wastewater discharged daily in nature. This rejection of raw sewage in 
natural environments is a common practice in most developing countries. Brought into direct contact with the receiving environment, raw sewage generates adverse effects including: a nuisance due to the stagnation of these waters and the release of offensive odors disturbance of the ecological balance of the natural environment, especially the pollution of surface water and groundwater and microbiological health risk or parasitic contamination [13].

Due to the significance of the faecal-oral route transmission for many bacterial food-borne diseases, basic hygiene measures assume a decisive importance in food safety management [14]. Great attention should therefore be given to the microbiological safety of these products because their direct consumption may cause health hazard to the consumer. Similar results were found on the other street foods. The germs most identified in these foods are mainly staphylococci and enteric bacteria. According to FAO/WHO [15], epidemiological data in hospital showed a prevalence of $19 \%$ of diarrheal disease worldwide and bacterial diarrhea was estimated between $20 \%$ and $70 \%$ of cases. The causes were related to poor hygiene found in the assessment of hazards and identification of critical points in the food processing chain [16]. In Africa, several studies on street food showed that their hygienic quality is very poor and this is a clear risk on the health of consumers [17]. These precarious hygiene conditions promote the risk of fecal contamination and therefore the recurrence risk of food borne illness. Based on these results, despite the high nutritional potential of Lesser African Threadfin dried-fermented, more attention (in the process and storage methods) should be paid to its microbial quality in order to preserve consumers' health.

\section{Conclusion}

This survey underlined the nutritional potential and the risk of contamination of Lesser African Threadfin dryedfermented. Microbiological standards have not been put in place during the process. Then, it's advisable that relevant quality control unit should be reactivated to assess the quality of ready-to-eat food, and particularly the fermented fishes.

\section{Acknowledgements}

The authors are grateful to the Food Engineering Technology Department of Polytechnic School of AbomeyCalavi University (UAC) for their financial support. They also like to thank Mrs Fatiyath Gbadamassi and Christelle Azonhitodé for their technical support.

\section{REFERENCES}

[1] FAO, "United Nations Food and Agriculture Organiza- tion,” Fishery Statistics Capture Production, FAO Yearbook, Vol. 86, 2000, p. 100.

[2] S. Tossou, "Rapport National D'évaluation de L'application des Mesures Sanitaires et Phytosanitaires Dans la Commercialisation des Produits de la Pêche au Bénin," Ministère de l'Agriculture , de l'Elevage et de la Pêche (MAEP), Bénin, 2010, p. 81.

[3] V. B. Anihouvi, J. D. Hounhouigan and G. S. Ayernor, "La Production et la Commercialisation du Lanhouin, un Condiment à Base de Poisson Fermenté du Golfe du Bénin,” Cahiers Agricultures, Vol. 14, No. 3, 2005, pp. 23-330.

[4] P. Dossou-Yovo, R. G. Josse, I. Bokossa and I. Palaguina, "Survey of the Improvement of Fish Fermentation for lanhouin Production in Benin,” African Journal of Food Science, Vol. 5, No. 17, 2011, pp. 878-883.

[5] C. H. Collins, P. M. Lyne and J. M. Grange, "Microbiological Methods," 7th Edition, Butterworth/Heinemann Ltd G-B, Germany, 1993, p. 67.

[6] R. J. De Knegt and H. V. D. Brink, "Improvement of the Drying Oven Method for the Determination of the Moisture Content of Milk Powder," International Dairy Journal, Vol. 8, No. 8, 1998, pp. 733-738.

http://dx.doi.org/10.1016/S0958-6946(97)00110-6

[7] A. A. Oshodi, "Proximate Composition, Nutritionally Valuable Minerals and Functional Properties of Adenopus breviflorus Benth Seed Flour and Protein Concentrate," Food Chemistry, Vol. 45, No. 2, 1992, pp. 79-83. http://dx.doi.org/10.1016/0308-8146(92)90013-R

[8] AOAC, "Official Methods of Analysis," Association of Official Analytical Chemist Inc., Virginia, 1990.

[9] H. L. Alder and E. B. Roessler, "Introduction to Probability and Statistics," 6th Edition, Freeman W.H., San Francisco, 1977, p. 426.

[10] A. E. Ogbeibu, "Biostatistics, a Practical Approach to Research and Data Handling,” Mindex Publishing Company Ltd., Benin City, 2005, p. 264.

[11] D. C. Hatton and D. A. Mc Carron, "Dietary Calcium and Blood Pressure in Experimental Models of Hypertension," Hypertension, Vol. 23, 1994, pp. 513- 514. http://dx.doi.org/10.1161/01.HYP.23.4.513

[12] R. Flores, "Health and Nutrition: Emerging and Reemerging Issues in Developing Countries,” In: Pinstrup-Andersen and R. Pandya-Loveh, Eds., The Unfinished Agenda: Perspectives on Overcoming Hunger Poverty and Environmental Degradation, International Food Policy Research Institute, Washington DC, 2001.

[13] G. J. Sawadogo, A. Téko-agbo and Y. Akpo, "Réutilisation des Eaux Usées en Agriculture au Sénégal: Impact sur la Santé et L'environnement in Compte Rendu Atelier-Séminaire sur Traitement et Réutilisation des Eaux Usées: Impact sur la Santé et L’environnement,” Acte de l'Atelier Scientifique du 3-6 Mars, IAV, Rabat, 2005, 14 pages.

[14] F. Untermann, “Microbial Hazards of Food,” Food Control, Vol. 9, No. 2-3, 1998, pp. 119-126. http://dx.doi.org/10.1016/S0956-7135(97)00067-4

[15] WHO/FAO, "Forty-Ninth Meeting of the Joint Expert 
Committee on Food Additives," Food and Agricultural Organization of the United Nation, Rome, 1998, p. 140.

[16] H. Leclerc, L. Schwarrtzbrod and E. Dei-Cas, "Microbial Agents Associated with Waterborne Diseases," Critical Reviews in Microbiology, Vol. 28, No. 4, 2002, pp. 371409. http://dx.doi.org/10.1080/1040-840291046768
[17] F. Rampersad, S. Laloo, A. Laborde, K. Maharaj, L. Sookhai, J. Teelucksingh and S. Reid, "Bacteriological Quality of Raw Oysters in Trinidad and the Attitudes, Knowledge and Perceptions of the Public about Its Consumption,” Epidemiology \& Infection, Vol. 123, No. 2, 1999, pp. 241-251.

http://dx.doi.org/10.1017/S0950268899002873 